\title{
Correction to: Trade, Investment and Politics: Prospects for Russian Economic Cooperation with the Gulf
}

\author{
Duncan Allan
}

Correction to:

Chapter 6 in: N. Kozhanov (ed.), Russia's Relations with the GCC and Iran, https://doi.org/10.1007/978-981-33-4730-4_6

The original version of Chapter 6 was inadvertently published with the second paragraph of the abstract preceding the Introduction. The paragraph has been removed from the chapter.

The updated version of this chapter can be found at https://doi.org/10.1007/978-981-33-4730-4_6

(C) The Author(s), under exclusive license to Springer Nature $\mathrm{Cl}$ Singapore Pte Ltd. 2021

N. Kozhanov (ed.), Russia's Relations with the GCC and Iran, https://doi.org/10.1007/978-981-33-4730-4_13 